Article

\title{
Effects of Taenia Pisiformis Infection and Obesity on Clinical Parameters, Organometry and Fat Distribution in Male Rabbits
}

\author{
David Arias-Hernández ${ }^{1}$, , Sara García-Jiménez ${ }^{2}$, Rosa Domínguez-Roldan ${ }^{1}$, \\ Clara Murcia-Mejía ${ }^{3}$, Armida Báez-Saldaña ${ }^{4}$ (D) Claudia Hallal-Calleros ${ }^{1, * \mathbb{D}}$ and \\ Ivan Flores-Pérez ${ }^{1, *}$ \\ 1 Facultad de Ciencias Agropecuarias, Universidad Autónoma del Estado de Morelos; \\ Cuernavaca 62209, Mexico; dariasher@hotmail.com (D.A.-H.); rosa.dguez88@gmail.com (R.D.-R.) \\ 2 Facultad de Farmacia, Universidad Autónoma del Estado de Morelos, Cuernavaca 62209, Mexico; \\ saragarcia@uaem.mx \\ 3 Facultad de Medicina Veterinaria y Zootecnia, Universidad Nacional Autónoma de México, \\ Mexico City 04510, Mexico; murcia@unam.mx \\ 4 Instituto de Investigaciones Biomédicas, Universidad Nacional Autónoma de México, \\ Mexico City 04510, Mexico; armida@biomedicas.unam.mx \\ * Correspondence: challalc@gmail.com (C.H.-C.); ivan.flores@uaem.mx (I.F.-P.); Tel.: +527771256435 (I.F.-P.)
}

Received: 8 August 2020; Accepted: 1 October 2020; Published: 22 October 2020

\begin{abstract}
Taenia pisiformis infection causes important economic loss in farms. It is suggested that obesity has a major impact on infection and reproduction. We addressed the impact of T. pisiformis infection in normal and obese rabbits to evaluate its effect on parameters important in behavior and reproduction. T. pisiformis infection in obese rabbits decreased body weight. In the obese-infected rabbits, eosinophils and heterophiles were increased $23 \%$ by the infection $(P \leq 0.05)$. T. pisiformis decreased cholesterol by $13 \%$ in normal weight infected rabbits and $10 \%$ in obese group $(P \leq 0.05)$, while triglyceride and VLDL were increased by $23 \%$ and $45 \%$ in the non-infected obese group $(P \leq 0.05)$. The infection increased serum cortisol levels only in normal weight rabbits $(P \leq 0.05)$. Liver weight was $20 \%$ higher in obese and obese-infected rabbits $(P \leq 0.05)$. Testicular weight in obese-infected was $46 \%$ higher than normal weight $(P \leq 0.0001)$ and $20 \%$ more than the obese-non-infected $(P \leq 0.0001)$. Furthermore, the infection reduced the weight of submandibular glands in infected and obese-infected rabbits $(P \leq 0.05)$, body fat increased $10 \%$ in the obese-infected than in the obese, and infected group was $35 \%$ over the normal weight non-infected $(P \leq 0.01)$. Our results show that $T$. pisiformis alters metabolic characteristics in rabbits, which can impact on the production and welfare of animals.
\end{abstract}

Keywords: cortisol; comorbidity; fat redistribution; parasites

\section{Introduction}

Parasitic diseases affect a third of the world population; both humans and animals are parasitized at some stage of their lives [1]. The metacestode of Taenia pisiformis (T. pisiformis) is a very frequent parasite in farm rabbits and in pets, being very frequently found in lactating and pregnant wild does [2]. It has been documented that infection in rabbits reduces litter size by $50 \%$, with an increase in serum progesterone levels [3]; the adult stage of T. pisiformis causes behavior modifications in experimentally infected hamsters [4] and the metacestode in domestic rabbits [5]. Obesity has been identified in rabbits, dogs, cats, pigs, and other animals, which are commonly considered obese when they are $20 \%$ over their ideal weight [6]. In rabbits, obesity occurs in farms mainly in breeding does and bucks, in experimental rabbits, and significantly in companion animals. However, to date, the information regarding the 
alterations of clinical parameters associated with obesity in the domestic rabbit and the obesity-infection comorbidity are poorly understood. Adipose tissue, besides storing fat, secretes hormones, for what it is considered the largest endocrine organ in the body. The amount of adipose tissue depends on factors such as age, physical activity, and genetics [7], but the impact of factors as infection diseases has not been cleared. Parasitism by cestodes in conditions of obesity has been scarcely studied in animals and humans. However, it has been reported that in obese mice infected with the nematode Nippostrongylus brasilensis the weight gain decreased and it was associated with a better metabolism of glucose, with a reduction of adipose tissue and hepatic steatosis, and also with a modified pattern of hormone expression related to metabolism. Considering these findings, it was proposed that infection by nematodes can have preventive or therapeutic effects in the development of obesity and its associated metabolic disorders [8]. It has also been documented that infections with parasites in humans can modify the lipid profile [1], and in mice, Schistosoma mansoni can reduce serum cholesterol levels by modulating lipid metabolism, thus counteracting the effect of atherogenic diets [9]. In addition, it has been observed that patients infected with the protozoa Giardia lamblia present lower levels of total cholesterol and LDL compared to healthy individuals [1]. In the case of cestodes, specifically in male mice infected with Taenia crassiceps, it was found an increase in the number of macrophages in the luminal space and in the seminiferous tubules, and morphological abnormalities in somatic cells (Sertoli and Leydig cells) and in germ cells [10]. The increase in visceral adipose tissue is associated with glucose intolerance and insulin resistance, which is directly correlated with the content of triglycerides in the liver [11]. In rabbits fed an obesogenic diet for 12 weeks, an increase in body weight and liver size was observed. They also had a significant increase in visceral fat, having histometric changes in the liver and testicles [12]. In the present study, we determined the effect of the infection with T. pisiformis eggs in obese, as opposed to normal weight rabbits; addressing some clinical parameters such as lipid profile, blood cells, hepatic enzymes and serum cortisol levels, in addition to the distribution of adipose tissue, and organometric changes in the size and weight of chinning glands and testicles.

\section{Results}

\subsection{Body Weight and Weight Gain}

Rabbits fed a high fat diet (HFD) for 56 days reached one kilogram more weight than rabbits fed with the maintenance diet, which represents $24 \%$ more weight (Figure 1). On day 56 post infection, the weight of the normal weight infected group was lower in relation to the normal weight control group (control vs. infected, $3.67 \pm 0.06$ vs. $3.55 \pm 0.06, P \leq 0.0001$ ). Similarly, the obese-infected group had a lower weight $(4.26 \pm 0.06)$ compared to the weight of the obese group without infection $(4.47 \pm 0.19)$ $(P \leq 0.0001)$ (Figure 1$).$

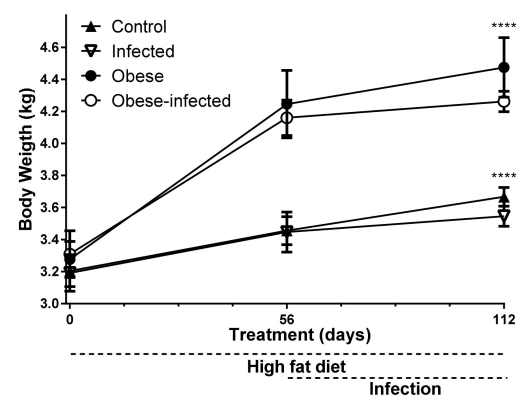

Figure 1. Weight at days zero, 56 (time of infection) and 112 (end of the experiment); the obese and obese-infected groups were fed a high-fat diet during 56 days previous to infection. The infection of the infected and obese-infected groups was performed with 3000 eggs of T. pisiformis 56 days after diet. Data show the mean $\pm \mathrm{SD},{ }^{* * *} P \leq 0.0001$, ANOVA test, followed by a Tukey's post hoc test. 


\subsection{Clinical Parameters}

\subsubsection{Complete Blood Count, Liver Enzymes and Lipid Profile}

Values obtained in the blood count are shown in Table 1, where the changes induced by chronic infection with T. pisiformis eggs are observed, compared against the control group. Total red and white blood cells did not show differences between groups; however, eosinophils increased $23 \%$ in the infected group $(P \leq 0.05)$ and heterophiles increased by $22 \%$ in the obese-infected group $(P \leq 0.05)$; in the lymphocytic, monocytic and basophilic blood cells no differences were observed between the groups. The mean corpuscular hemoglobin (MHC) and mean corpuscular hemoglobin concentration (MCHC) values were also similar in all groups. Serum levels of the liver enzyme alanine aminotransferase (ALT) and aspartate aminotransferase (AST) were unchanged in the comparison between groups. Cholesterol decreased by $13 \%$ in the normal weight infected rabbits $(P \leq 0.01)$ and by $10 \%$ in obese-infected rabbits $(P \leq 0.05)$ compared to the control group. In the obese group, triglycerides and VLDL increased by $23 \%(P \leq 0.05)$ and $45 \%(P \leq 0.01)$, respectively, compared against the control group (Table 1$)$, and HDL decrease by $16 \%$ in obese-infected compared against the obese group $(P \leq 0.01)$ (Table 1$)$.

Table 1. Complete blood count, liver enzymes and lipid profile of rabbits at day 56 after infection with T. pisiformis eggs.

\begin{tabular}{cccccc}
\hline Analyte & Control & Infected & Obese & Obese-Infected & Reference Values \\
\hline RBC $\left(\times 10^{12}\right)$ & $6.4 \pm 0.2$ & $6.8 \pm 0.2$ & $6.6 \pm 0.5$ & $6.7 \pm 0.3$ & $6-6.8[13]$ \\
\hline WBC $\left(\times 10^{9}\right)$ & $6.9 \pm 1.3$ & $7.3 \pm 1.1$ & $6.3 \pm 1.4$ & $6.6 \pm 0.9$ & $6.8-9.7[13]$ \\
\hline Lymphocytes $(\%)$ & $44.8 \pm 2.5$ & $43.3 \pm 4.5$ & $44.7 \pm 9$ & $38.2 \pm 3.4$ & $39-67[13]$ \\
\hline Eosinophils $(\%)$ & $3.5 \pm 0.2$ & $4.3 \pm 1.1^{\mathrm{a}}$ & $2.3 \pm 1$ & $1.8 \pm 1.1^{\mathrm{b}}$ & $1-2[13]$ \\
\hline Neutrophils $(\%)$ & $45.3 \pm 2.4$ & $45.7 \pm 3.6^{\mathrm{a}}$ & $46.7 \pm 9.1^{\mathrm{a}}$ & $55.5 \pm 4.2^{*} \mathrm{~b}$ & $25-46[13]$ \\
\hline Basophils $(\%)$ & $1.5 \pm 1$ & $1.7 \pm 0.5$ & $2.3 \pm 1.4$ & $1.3 \pm 0.5$ & $2.1-5[13]$ \\
\hline Monocytes $(\%)$ & $4.8 \pm 2.3$ & $5 \pm 1.3$ & $4 \pm 1.7$ & $3.2 \pm 2$ & $1-8[13]$ \\
\hline MCH $(\mathrm{Pg})$ & $19.5 \pm 0.6$ & $19.6 \pm 0.5$ & $19.8 \pm 0.8$ & $19.5 \pm 0.4$ & $20-21[13]$ \\
\hline MCHC $(\mathrm{g} / \mathrm{dL})$ & $30.5 \pm 0.5$ & $30.3 \pm 0.5$ & $30.2 \pm 0.5$ & $29.7 \pm 0.2$ & $32-34[13]$ \\
\hline AST(IU/L) & $20.4 \pm 5.6$ & $16.4 \pm 8.1$ & $18.6 \pm 7.8$ & $19.2 \pm 6.6$ & $14-80[14]$ \\
\hline ALT(IU/L) & $22.8 \pm 3$ & $20.9 \pm 6.6$ & $18.2 \pm 4.8$ & $20.6 \pm 6.5$ & $14-113[14]$ \\
\hline Cholesterol $(\mathrm{mg} / \mathrm{dL})$ & $101.9 \pm 4.5$ & $88.3 \pm 4.3^{*, \mathrm{a}}$ & $103.1 \pm 3.8^{\mathrm{b}}$ & $91.3 \pm 2.2^{*, \mathrm{a}}$ & $10-80[14]$ \\
\hline Triglycerides $(\mathrm{mg} / \mathrm{dL})$ & $93.6 \pm 12.4$ & $91.3 \pm 11^{\mathrm{a}}$ & $115.3 \pm 9.9^{*, \mathrm{~b}}$ & $81.3 \pm 5.7^{\mathrm{a}}$ & $15-160[14]$ \\
\hline HDL $(\mathrm{mg} / \mathrm{dL})$ & $51.04 \pm 4.3$ & $47.2 \pm 4.5$ & $52.7 \pm 3.5^{\mathrm{a}}$ & $44.2 \pm 2.6^{\mathrm{b}}$ & $46-58[14]$ \\
\hline VLDL $(\mathrm{mg} / \mathrm{dL})$ & $17.8 \pm 2.57$ & $19.3 \pm 2.8^{\mathrm{a}}$ & $25.8 \pm 3^{*, \mathrm{~b}}$ & $16.2 \pm 1.1^{\mathrm{a}}$ & $9-15[14]$ \\
\hline
\end{tabular}

RBC, red blood cells; WBC, White blood cells; $\mathrm{MCH}$, mean corpuscular hemoglobin; MCHC, mean corpuscular hemoglobin concentration; AST, Aspartate aminotransferase; ALT, Alanine aminotransferase. Values are expressed as mean \pm SD. ${ }^{*}$ Indicates differences between groups compared to control. Different letter indicates differences between treatments; $P \leq 0.05$, ANOVA test, followed by aTukey's post hoc test.

\subsubsection{Serum Cortisol}

The levels of serum cortisol in normal weight infected animals showed an increase with respect to the control group $(P=0.0132)$. The comparison between the obese and obese-infected groups showed no difference (Figure 2); although a trend is observed, they were not considered different, since the mean for the obese group was $10.37 \pm 4.65$ while that of the infected obese group was $4.84 \pm 1.12(P=0.052)$. 


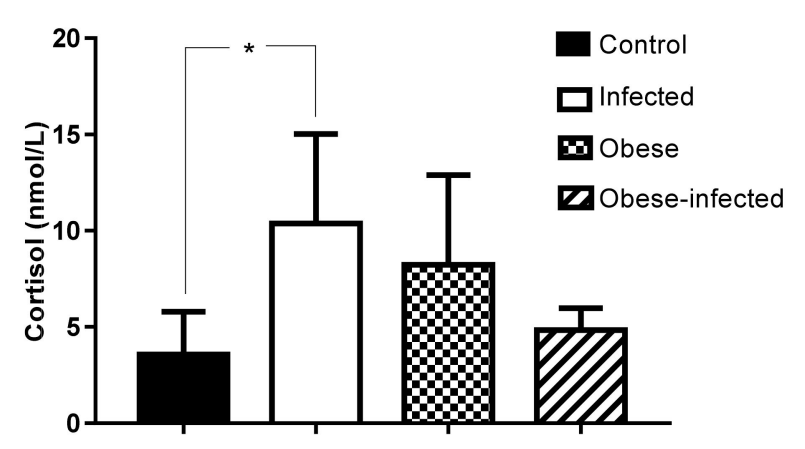

Figure 2. Serum cortisol levels were measured at day 56 post infection in rabbits infected with T. pisiformis. Data show mean $\pm \mathrm{SD},{ }^{*} P \leq 0.05$, ANOVA test, followed by a Tukey's post hoc test.

\subsection{Parasite Load}

The analysis at necropsy allowed to observe a higher number of liver granulomas in the infected group, where a total of 25 granulomas were observed in the $85 \%$ of the animals. In the obese-infected group, metacestodes were found in $100 \%$ of the rabbits, with a range from 4 to 22 metacestodes (Table 2).

Table 2. Number of liver granulomas and metacestodes found at necropsy in rabbits infected with eggs of T. pisiformis after 56 days post-infection.

\begin{tabular}{ccccc}
\hline \multirow{2}{*}{ Rabbit } & \multicolumn{2}{c}{ Granulomas } & \multicolumn{2}{c}{ Metacestodes } \\
\cline { 2 - 5 } & Infected & Obese-Infected & Infected & Obese-Infected \\
\hline 1 & 1 & 0 & 5 & 4 \\
\hline 2 & 6 & 0 & 2 & 13 \\
\hline 3 & 3 & 0 & 7 & 22 \\
\hline 4 & 2 & 1 & 10 & 7 \\
\hline 5 & 0 & 0 & 5 & 21 \\
\hline 6 & 10 & 0 & 7 & 7 \\
\hline 7 & 3 & 3 & 5 & $13.1 \pm 7.3 *$ \\
\hline Mean \pm SD & $3.6 \pm 3.4$ & $0.6 \pm 1.1 *$ & $5.8 \pm 2.5$ & 92 \\
\hline Total & 25 & 4 & 41 & *
\end{tabular}

\subsection{Organometric Changes}

\subsubsection{Weight of Liver, Testicles and Submandibular Glands}

Liver weight was $20 \%$ higher in the obese and obese-infected groups ( $P \leq 0.05$, Figure 3a). However, the percentage of the liver weight with respect to the body weight of the rabbits was not affected in the different experimental groups (Figure 4a). The testicles of obese-infected rabbits had a $44 \%$ increase in weight (right testicle, $P \leq 0.0001$, Figure $3 b$ ) and $49 \%$ (left testicle, $P \leq 0.0001$, Figure $3 c$ ). They also had a higher weight in the obese group, resulting in a $21 \%$ increase in the right testicle $(P \leq 0.01$, Figure $3 b)$ and a $20 \%$ in the left testicle $(P \leq 0.0001$, Figure $3 c)$. The comparison of the right testicle versus the left testicle in the same group was performed in all the groups and showed no weight differences. The weight of the submandibular glands was lower in the infected and obese-infected groups compared to the control group $(P \leq 0.05)$. It was also observed that the weight was lower in the 
glands of the obese-infected versus the obese group $(P \leq 0.05)$ (Figure $3 d, e)$. In the obese-infected group the left submandibular gland is heavier than the right $(0.85 \pm 0.03 \mathrm{~g}$ and $0.74 \pm 0.03 \mathrm{~g}$, respectively; $P=0.0103)$.
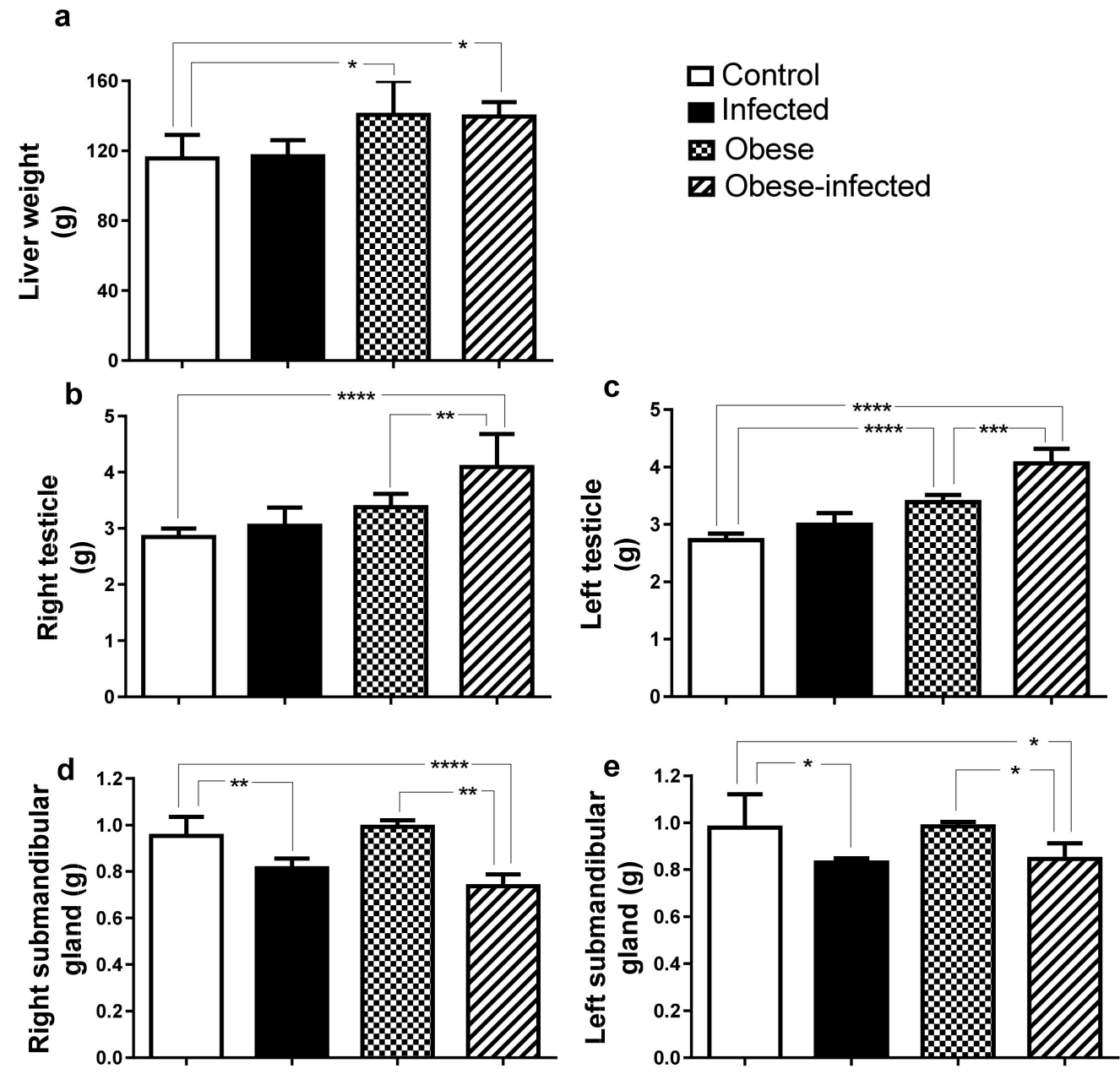

Figure 3. Weight of the liver, testicles and submandibular glands in rabbits infected with T. pisiformis. (a) Liver, (b) Right testicle, (c) Left testicle, (d) Right and left submandibular weight (e). Data show mean \pm SD. ${ }^{*} P \leq 0.05,{ }^{* *} P \leq 0.01,{ }^{* * *} P \leq 0.001,{ }^{* * * *} P \leq 0.0001$, ANOVA test, followed by a Tukey's post hoc test.

\subsubsection{Percentages of Weight of Liver, Testicles and Submandibular Glands}

The percentage of testicular weight was higher in obese-infected rabbits compared to those in the control group $(0.19 \pm 0.0157$ vs. $0.15 \pm 0.0073, P \leq 0.001)$. This increase was also observed when obese rabbits were compared to obese-infected $(0.15 \pm 0.0144$ vs. $0.19 \pm 0.0157, P \leq 0.01)$ (Figure $4 b)$. The percentage of weight of the submandibular glands decreased in the three experimental groups when compared against control; a 11.6\% reduction in weight was observed in the infected group, $15.4 \%$ less in the obese group $(P \leq 0.001)$ and $28.84 \%$ less in obese-infected group $(P \leq 0.01)$. A decrease was also observed when contrasting the obese-infected group against the obese group $(P \leq 0.01)$ (Figure $4 \mathrm{c}$ ). 

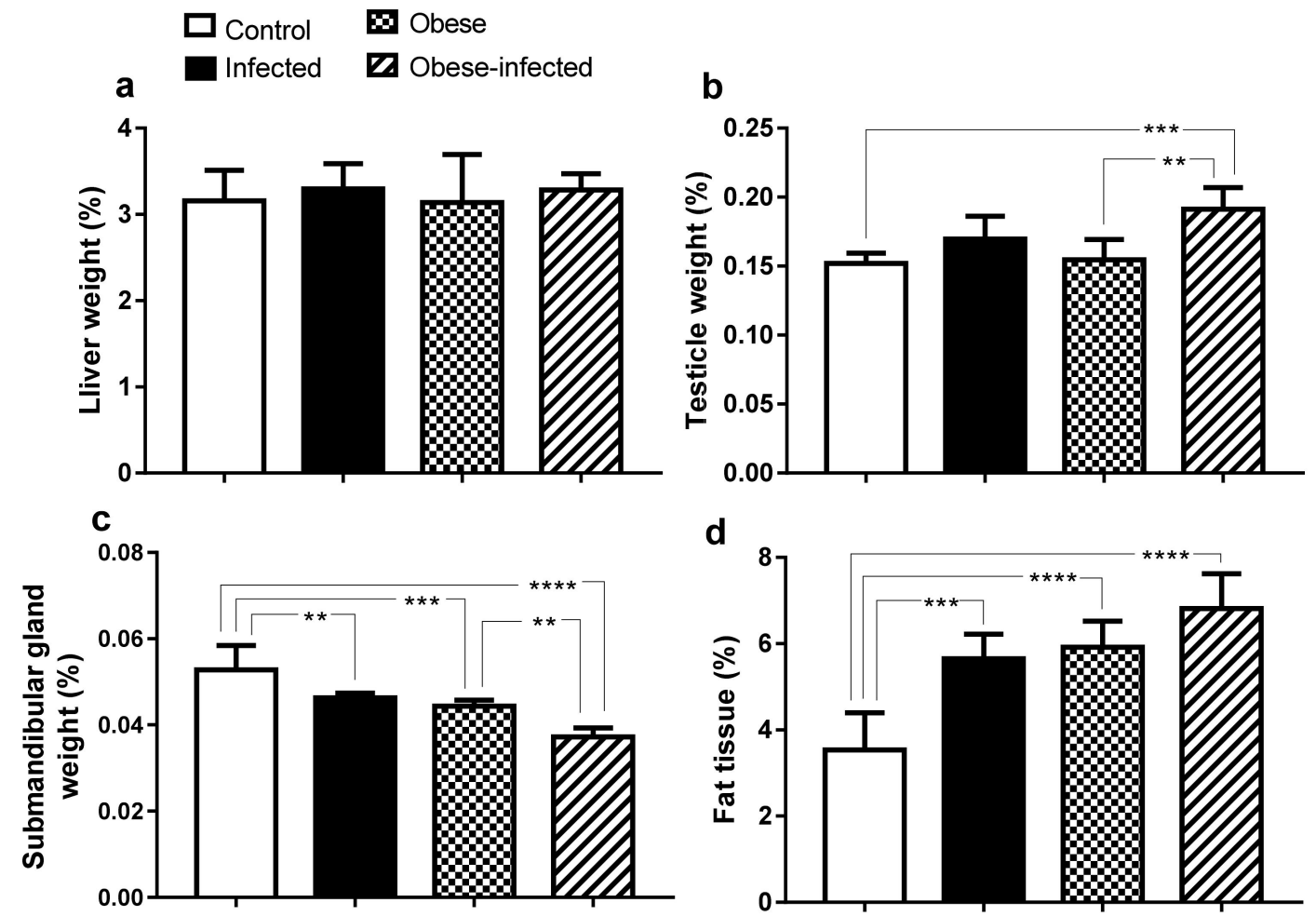

Figure 4. Proportion of the weight of the liver, testes, submandibular glands and adipose tissue in relation to the body weight of rabbits infected with T. pisiformis. (a) Percentage of the liver weight, (b) Percentage of the testicular weight, (c) Percentage of the weight of the submandibular glands and

(d) Percentage of the weight of the adipose tissue. Data show mean \pm SD. ${ }^{* *} P \leq 0.01,{ }^{* * *} P \leq 0.001$, **** $P \leq 0.0001$, ANOVA test, followed by a Tukey's post hoc test.

\subsection{Distribution of Adipose Tissue}

Total adipose tissue increased in all three experimental groups with respect to control. In infected rabbits, an increase of more than $50 \%$ was observed (129.8 \pm 30.6 vs. $200.6 \pm 20.4 \mathrm{~g}, P \leq 0.01)$, whereas in the obese group twice as much adipose tissue was observed $(263.5 \pm 29.5 \mathrm{~g}(P \leq 0.0001)$, and in obese-infected it increased $223 \%(290.2 \pm 35.6 \mathrm{~g}, P \leq 0.0001)$. When comparing between groups, the obese $(P=0.0073)$ and the obese-infected $(P=0.0002)$ resulted in a higher amount of adipose tissue in relation to the infected group (Figure $5 \mathrm{a}$ ).

We studied the body distribution of adipose tissue in the suprascapular region, the visceral region, the perirenal region, and the peritesticular region. In the suprascapular region adipose tissue increased 1.7 times in the obese group and 1.4 times in the obese-infected compared with the control $(P \leq 0.0001)$ (Figure 5b). Adipose visceral tissue also increased 1.27 times in the obese $(P=0.011)$ and 1.3 times in obese-infected $(P=0.007)$ with respect to control (Figure $5 \mathrm{c})$. The adipose tissue of the perirenal region increased $70 \%$ in the infected rabbits in relation to the control group $(80.72 \pm 24.6 \mathrm{~g}$ vs. $138.7 \pm 13.2 \mathrm{~g}$, $P=0.001)$; the obese group increased an $80 \%$ its adipose tissue content $(148.5 \pm 29.13 \mathrm{~g}, P=0.0003)$ and the obese-infected group $(175.7 \pm 23.2 \mathrm{~g})$ doubled it $(217 \%, P \leq 0.0001)$ (Figure $5 \mathrm{~d})$. Regarding the peritesticular adipose tissue, the obese-infected group $(14.9 \pm 3.9 \mathrm{~g})$, increased twice compared against control $(7.3 \pm 1.7 \mathrm{~g}$ vs. $14.9 \pm 3.9, P \leq 0.0001)$, infected $(6.7 \pm 0.6 \mathrm{~g}, P<0.0001)$ or obese groups $(9.3 \pm 1.9 \mathrm{~g}, P=0.0025)$ (Figure 5e). 


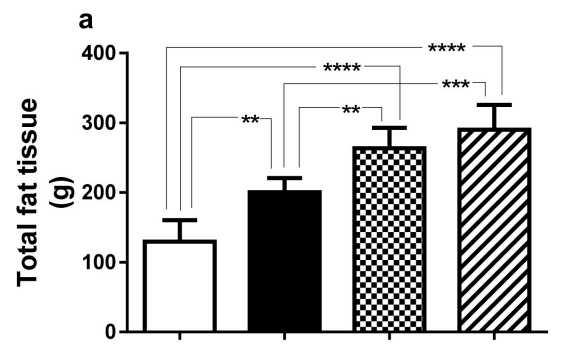

\author{
$\square$ Control \\ Infected \\ Obese \\ $\square$ Obese-infected
}
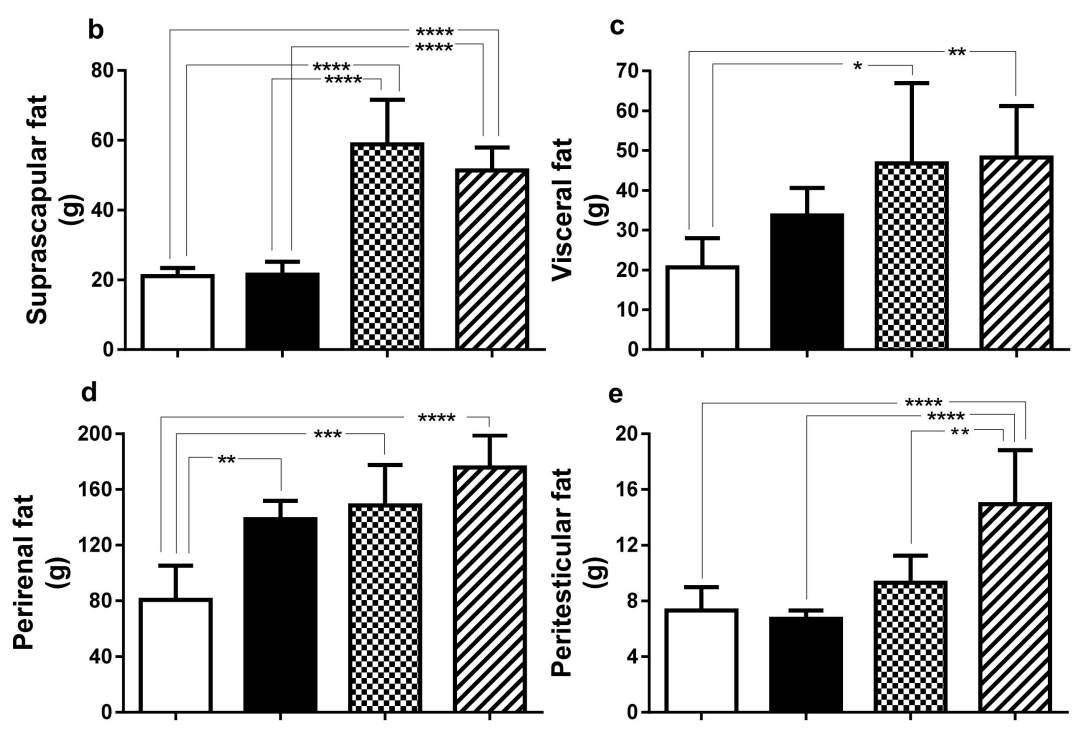

Figure 5. Distribution of body adipose tissue in rabbits infected with T. pisiformis. (a) weight of total adipose tissue, (b) suprascapular, (c) visceral, (d) perirenal, and (e) peritesticular. Data show mean \pm SD. ${ }^{*} P \leq 0.05,{ }^{* *} P \leq 0.01,{ }^{* * *} P \leq 0.001,{ }^{* * * *} P \leq 0.0001$, ANOVA test, followed by a Tukey's post hoc test.

Percentage of Body Adipose Tissue

The percentage of adipose tissue revealed an increase in obese-infected $(6.81 \pm 0.80)(P \leq 0.0001)$ and in infected rabbits $(5.6 \pm 0.57)(P \leq 0.001)$, compared with $3.53 \pm 0.86$ in the control group, besides that the obese group also increased its percentage of adipose tissue $(5.91 \pm 0.60)(P \leq 0.05)$ (Figure $4 \mathrm{~d})$.

\title{
2.6. Percentage of Re-Distribution of the Adipose Tissue in the Different Anatomical Sites
}

Table 3 shows changes in the localization of adipose tissue. The comparison of perirenal adipose tissue among the different groups showed a higher percentage in the infected group than in the obese group ( $69 \pm 2 \%$ vs. $56 \pm 9 \%, P \leq 0.01)$. The percentage of suprascapular tissue was highest in the obese group $(23 \pm 6 \%)$ compared to the control group $(17 \pm 4.3 \%)(P \leq 0.05)$, the infected group $(11 \pm 1.7 \%)(P \leq 0.001)$ and the obese-infected $(18 \pm 1 \%)(P \leq 0.05)$.

Table 3. Changes in the localization of adipose tissue induced by infection.

\begin{tabular}{ccccc}
\hline Adipose Tissue (\%) & Control & Infected & Obese & Obese-Infected \\
\hline Perirenal & $61 \pm 5.2$ & $69 \pm 2.5^{\mathrm{a}}$ & $56 \pm 8.6^{\mathrm{b}}$ & $60 \pm 3.6$ \\
\hline Suprascapular & $17 \pm 4.3$ & $11 \pm 1.7^{*, \mathrm{a}}$ & $23 \pm 5.6^{*}$ & $18 \pm 1.0^{\mathrm{b}}$ \\
\hline Visceral & $16 \pm 3.0$ & $17 \pm 2$ & $18 \pm 7.3$ & $17 \pm 3.4$ \\
\hline Peritesticular & $6 \pm 2.4$ & $3 \pm 0.4^{*}$ & $3 \pm 0.5^{*}$ & $5 \pm 1.3$
\end{tabular}

Values are expressed as mean \pm SD. ${ }^{*}$ Indicates differences of groups versus control. Different letter indicates differences between treatments; $P \leq 0.05$, ANOVA test, followed by a Tukey's post hoc test. 
There is a decrease in the infected groups (control vs. infected and obese vs. obese-infected). In the percentage of adipose tissue accumulated in the mesentery no difference was observed. Finally, the percentage of peritesticular tissue was higher in the control group $(6 \pm 2.4 \%)$ compared to the infected $(3 \pm 0.4 \%)(P \leq 0.05)$ and obese groups $(3 \pm 0.5 \%)(P \leq 0.05)$.

\section{Discussion}

In the current work, obese rabbits developed a higher number of T. pisiformis metacestodes. In animal models and in humans in which the interaction between obesity and infectious diseases has been studied, it has been suggested that obesity increases the susceptibility to infection by bacteria, viruses and protozoa [15], with not previous studies of cestodes infection. The mechanism by which obesity facilitates infection is not well known, however, in some studies in obese mice infected with Klebsiella pneumoniae [16] or with Mycobacterium tuberculosis [17], a delayed immune response against the pathogen was evidenced. In addition, the phagocytic function was not efficient for the exclusion of the pathogen, which generated a higher mortality.

In our obesity model, infection with T. pisiformis decreased body weight at day 56 post infection, affecting mainly obese rabbits, and we also observed a trend to reduce weight gain in normal weight infected rabbits. This data is consistent with the observations in rats infected with the nematode N. brasilensis, where the infection induced weight loss [18]. Moreover, in mice subjected to a cafeteria diet, a higher frequency of infection with the influenza virus and higher mortality rate was observed. This observation was attributed to a decrease in chemical mediators such as IFN- $\alpha$ and IFN- $\beta$, as well as a reduction in the cytotoxic capacity of NK cells [19]. This finding is consistent with our observation in the obese-infected rabbits, in which the total number of metacestodes was higher and all animals were infected; it is important to note that T. pisiformis is a parasite that naturally infects wild and domestic rabbits and hares [2,20]. Therefore, it is of interest to study the mechanisms associated with the susceptibility to infection observed in obese rabbits, especially the role of cytokines in this comorbidity.

Parasitic behavior in an obese host remains unknown [15]. Parasites such as Toxoplasma gondii induces a reduction in mortality, in parasitemia, and in cardiac damage in Chagas disease, postulating that adipose tissue functions as a shield by abducting parasites and preventing parasites migration to the heart [21]. In contrast, the infection with Plasmodium berghei in mice with hypothalamic obesity accentuates damage to the host, which present severe brain damage, high parasitic loads, and an increase in pro-inflammatory cytokines such as IL-12 and IFN- $\gamma$ [22]. In Malaria, caused by Plasmodium falciparum, obesity is considered as a risk factor in humans [23]. Our findings together show that in the case of infection by T. pisiformis, obesity is a factor that increases susceptibility, since obese-infected rabbits had a higher quantity of metacestodes. They also had a lower number of liver lesions attributable to changes in the physiology of the liver caused by obesity, since it has been proposed as an organ that mounts an immune response against the migration of the eggs of T. pisiformis, sequestering them through the formation of more granulomas and thus reducing the hatching and the number of metacestodes [24].

Total white and red cells count was not affected during the infection, however, eosinophilia was observed in the infected and heterophilia in the obese-infected rabbits. Our observations differ from a previous study where they reported that leukocytes increased from day 7 post infection until day 25 [5]. The differences may be related to the experimental conditions, since they used a different infective dose, observed different amounts of metacestodes lodged in the abdominal cavity of the rabbits, and also the sex of the rabbits was different. Eosinophilia has been reported in other parasitosis in rabbits; in case of infections with Ascaris suum, Toxocara canis and Toxocaris leonina, changes were observed in leukocytes, eosinophils and neutrophils, and the most marked eosinophilia was observed after 2 or 3 weeks after infection [25].

In the current work, infection by T. pisiformis eggs induced changes in lipid metabolism, since there was a decrease in serum cholesterol in both the infected and obese-infected groups. In obese an increase in triglycerides and VLDL was observed. These results agree with those reported for the infection with 
S. mansoni, a parasitosis that in mice causes a significant reduction in the serum lipid profile, and whose decrease was attributed to different metabolites that are synthesized by S. mansoni, arguing that they affect the liver tissue of the host [26]. In the case of cestodes, it was described that metacestodes of $T$. solium and T. crassiceps can synthesize androgens and estrogens through the transformation of certain precursors [27]. Lipids, particularly cholesterol and its metabolites, are required by some parasites [1]; this condition could explain the reduction of serum cholesterol levels in both obese and non-obese infected rabbits. Cholesterol reduction induced by parasitosis has been reported in humans. Natural infection with $S$. haematobium in obese individuals has a beneficial effect because it reduces the risk of developing cardiometabolic diseases [28]. Authors propose that the mechanism of the normalization of the lipid profile is due to the use of lipids in the synthesis of lipoproteins for the eggs of $S$. haematobium. This would also be a possibility in the infection with T. pisiformis.

Parasitic helminth infections usually induce immunosuppression. Cortisol is a hormone involved in the stress response, whose prolonged or excessive secretion can have physiological repercussions on the immune response and on reproductive functions [29,30]. The increase in serum cortisol in normal rabbits infected with T. pisiformis eggs, coincides with that previously observed in rabbits that were infected with Eimeria coecicola [31]; whereas in rabbits chronically infested with P. cuniculi, cortisol levels also tended to increase [32]. Furthermore, in obese patients, serum cortisol levels do not increase [33], coinciding with our observation in obese and obese-infected groups, where no increase in serum cortisol was observed. It is of interest to evaluate the function of the immune system and reproductive function in obese-infected rabbits.

In the current study it was observed that the liver weight of the rabbits was higher in the obese and in the obese-infected groups, this observation coincides with a previous work in which the high-fat diet and the increased weight in rabbits were associated with the infiltration of lipids into hepatocytes [12]. However, the increase in liver weight was proportional to the increase in body weight. The macroscopic evaluation performed on the livers showed $85 \%$ of the rabbits with fatty liver in the obese and obese-infected groups, whereas in the control and control-infected groups no changes were observed. The increase in visceral adipose tissue is associated with the triglycerides content of the liver [11], generating accumulation of lipids in the hepatocyte cytoplasm. This is associated with a progressive hepatic deterioration and with different degrees of liver fibrosis [34], supporting the increase in serum triglycerides and the increase in accumulated fatty tissue in obese rabbits.

Obese and infected rabbits with T. pisiformis eggs increased the weight of testicles, likewise in obese rabbits; it can be attributed to the fact that the parasite along with obesity could modify the host hormonal environment promoting the redistribution of adipose tissue to the testicles, since it has been described that the larval stage of T. crassiceps causes decreased testosterone and increased estradiol serum levels [35].

The infection with T. pisiformis caused a lower weight on the submandibular glands, both in normal weight (infected) and obese-infected groups. The submandibular glands in the rabbit are associated with sexual [36], territorial and hierarchical behavior of rabbits in both sexes $[37,38]$. The sexual and territorial function of the glands is dependent on the amount of serum testosterone in males [39], then, changes in submandibular glands could be attributed to modifications in serum testosterone levels. It was reported that rabbits induced to obesity and infected with T. pisiformis showed decreased chinning behavior, higher reaction time to mounts, and lower number of mounts [40]. These behaviors are highly associated with the level of serum testosterone.

In our study, suprascapular and visceral adipose tissue increased in obese-infected rabbits and peritesticular adipose tissue was increased in obese-infected rabbits. Studies in humans have shown that the distribution of adipose tissue are associated with risk to diseases. Excess of adipose tissue in the abdominal region, especially visceral adipose tissue, is associated with greater risks, although not all obese individuals develop the same pathologies or to the same degree of disease [41]. Our results partially coincide with those obtained in a study in rabbits fed a high fat diet in which an adipose tissue redistribution was observed, inducing central obesity and insulin resistance [42]. Although the 
etiology of obesity is multifactorial, it has been suggested that infection with specific pathogens can lead to an increase in adiposity $[43,44]$. In wild hares, it has been reported that the establishment of the larval stage of Taenia pisiformis presents a negative correlation with the body mass index, measured through the perirenal fat [45]. In this way, the changes observed in the distribution of adipose tissue in the different experimental circumstances could contribute to generate a more permissive environment for the development of the parasite, which involves changes in the immune and endocrine system.

\section{Conclusions}

Our findings indicate that the infection with T. pisiformis alters metabolic characteristics in the rabbit that can impact on the production and welfare of animals. These alterations are intensified in conditions of obesity. In future studies it will be important to clarify whether the infection with cestodes in obese individuals, has the ability to reverse the associated metabolic conditions such as metabolic syndrome and type II diabetes, and the relationship it maintains with the distribution of adipose tissue in the host, and not only to the amount of total fat. This work is a pioneer in characterizing the effects that infection by cestodes has on a natural host, in a bivalent scenario in which the obesity converges with the infection. It can be useful in veterinary clinical practice in which rabbits are diagnosed with obesity and there is also evidence in the clinical history of a probable infection with T. pisiformis. Furthermore, it can be useful as a study model in other parasitosis by cestodes such as T. solium, still prevalent in countries like Brazil, Mexico, and others. In addition, it opens the possibility of studying whether parasite antigens could contribute to the reduction of serum cholesterol.

\section{Materials and Methods}

\subsection{Animals, Diets and Groups}

Animal care and experimentation practices were followed with adherence to official Mexican regulations (NOM-062-ZOO-1999), which are in strict accordance with all applicable international, national, and institutional guidelines for the care and use of animals. Twenty-eight male New Zealand rabbits, 4.5 months old with an initial weight of $3.25 \pm 0.12 \mathrm{~kg}$ were used; they were kept in individual cages $(60 \times 90 \times 40 \mathrm{~cm})$ under farm conditions, with an average annual temperature of $19 \pm 3{ }^{\circ} \mathrm{C}$. The 28 rabbits were assigned randomly into four groups of 7 rabbits each, and were fed according to the corresponding experimental treatment, providing them with water ad libitum. The control and the infected groups were fed with $180 \mathrm{gr}$ of commercial maintenance pellets (Ganador ${ }^{\circledR}$, Malta Cleyton, Mexico, minimum content $16 \%$ protein, $3 \%$ fat and $17 \%$ fiber) [46]. The obese and obese-infected groups were fed a high-fat diet (HFD) composed of commercial maintenance pellets added with $5 \%$ soybean oil and $5 \%$ pork fat. The HFD was offered ad libitum for 8 weeks previous to the infection [47], and thorough the experiment.

\subsection{Infection}

T. pisiformis infection was performed after 56 days of HFD; T. pisiformis proglottids collected from infected dogs, washed, identified and maintained according to the method described by Flatt and Moses (1975) were macerated in 5\% saline in a mortar, and the viable eggs were quantified using a hemocytometer. The corresponding rabbits were inoculated with 3000 eggs via esophageal using a sterile plastic catheter [5].

\subsection{Complete Blood Count, Liver Enzymes and Lipid Profile}

At day 56 post infection, the rabbits were anesthetized with $35 / 5 \mathrm{mg} / \mathrm{kg}$ of ketamine/xylazine via IM [48]. A blood sample was obtained intracardiacally, separating a part of the whole blood in tubes with EDTA for the hematological analysis, which was performed with the Mindray BC-2800 analyzer equipment; another part of the blood was kept in tubes without anticoagulant, and serum obtained by centrifugation was used for the determination of cortisol, liver enzymes (alanine aminotransferase 
ALT and aspartate aminotransferase AST), and the lipid profile (triglycerides, cholesterol, high density lipoproteins HDL, very low density lipoproteins VLDL). The liver enzymes and lipid profile were determined using the specialized biochemical analysis equipment Roche COBAS C111, USA.

\subsection{Serum Cortisol}

Cortisol was measured in serum obtained individually at day 56 post infection and stored at $-20{ }^{\circ} \mathrm{C}$ until analysis. Serum cortisol levels were determined in duplicate using a commercial radioimmunoassay kit (Pantex, Santa Mónica, CA) [32].

\subsection{Humanitarian Sacrifice}

The humanitarian sacrifice of the rabbits was performed at day 56 post-infection by administration of a lethal dose of sodium pentobarbital $(100 \mathrm{mg} / \mathrm{kg})$, on previously anesthetized rabbits with ketamine/xylazine $(35 / 5 \mathrm{mg} / \mathrm{kg})[48]$.

\subsection{Parasite Load}

Metacestodes of T. pisiformis were found in the thoracic and abdominal cavities, and the number of granulomatous lesions in the liver were recorded. The granulomas were observed in the capsule and the superficial hepatic parenchyma of the complete liver, the count was made double blind, considering a different granuloma each lesion surrounded by healthy tissue. The animals that presented granulomatous liver lesions or metacestodes were considered as infected [5].

\subsection{Percentage of Tissue Weight}

The liver, submandibular glands and testicles were dissected and weighed on an analytical balance [12], and the tissue percentage weight was obtained with respect to the total body weight of the rabbit. For the submandibular glands and testicles, the percentage was obtained by taking the sum of the weight of both glands.

\subsection{Adipose Tissue}

Visceral (distributed in epiploon and mesentery), perirenal (surrounding the kidney) suprascapular (found on the subcutaneous dorsal region between the two scapulae) and peritesticular (surrounding the testicle) adipose tissue were collected separately and weighed on an analytical balance [42]. The percentage of adipose tissue was calculated with respect to the body weight of each rabbit.

\subsection{Statistical Analysis}

The body weight was analyzed using a 2-way repeated measures mixed model approach (groups as the treatment factor and weeks as the repeated factor), followed by a multiple Tukey's test. Number of metacestodes and hepatic granulomas were performed using a $t$-test. The following parameters were analyzed using a one-way analysis of variance (ANOVA) followed by the Tukey's multiple comparisons post hoc test to compare the responses between the different groups: weight gain, hemogram, hepatic enzymes, lipids, cortisol, liver, testicles and submandibular glands weight; percentage of liver, testicles and submandibular glands weight; total, suprascapular, visceral, peritesticular and perirenal adipose tissue. $P$ values $\leq 0.05$ were considered significant.

Author Contributions: Conceptualization, C.H.-C. and I.F.-P.; methodology, D.A.-H., S.G.-J., R.D.-R. and C.M.-M.; formal analysis, I.F.-P., D.A.-H.; original draft preparation, C.H.-C., D.A.-H.; all authors reviewed the manuscript; editing, C.H.-C. and D.A.-H.; supervision, R.D.-R. and A.B.-S.; funding acquisition, I.F.-P. and S.G.-J. All authors have read and agreed to the published version of the manuscript.

Funding: This research was partially funded by the Agreement UAEM-UNAM (42467-2177-8-IX-15).

Acknowledgments: D.A.-H. and R.D.-R. acknowledge the PhD fellowships 492304 and 273755 received from Consejo Nacional de Ciencia y Tecnología. Authors acknowledge technical support from Irene Lee-Rivera. 
Conflicts of Interest: The authors declare no conflict of interest.

\section{References}

1. Bansal, D.; Bhatti, H.S.; Sehgal, R. Role of cholesterol in parasitic infections. Lipids Heal. Dis. 2005, 4, 10. [CrossRef] [PubMed]

2. Domínguez-Roldan, R.; Pérez-Martínez, M.; Rosetti, M.F.; Arias-Hernández, D.; Bernal-Fernández, G.; Flores-Pérez, F.I.; Hallal-Calleros, C. High frequency of Taenia pisiformis metacestodes and high sex-associated susceptibility to cysticercosis in naturally infected wild rabbits. Parasitol. Res. 2018, 117, 2201-2206. [CrossRef] [PubMed]

3. Hallal-Calleros, C.; Morales-Montor, J.; Orihuela-Trujillo, A.; Togno-Peirce, C.; Murcia-Mejía, C.; Bielli, A.; Hoffman, K.L.; Flores-Pérez, F.I. Taenia pisiformis cysticercosis induces decreased prolificacy and increased progesterone levels in rabbits. Vet. Parasitol. 2016, 229, 50-53. [CrossRef] [PubMed]

4. Domínguez-Roldan, R.; Hallal-Calleros, C.; Edda, S.; Hernández, M.; Aguirre-Flores, V.; García-Jimenez, S.; Báez-Saldaña, A.; Flores-Pérez, F.I. Behavioral and hormonal changes associated with the infective dose in experimental taeniasis in golden hamsters (Mesocricetus auratus). Exp. Parasitol. 2016, 166, 173-180. [CrossRef] [PubMed]

5. Betancourt-Alonso, M.A.; Orihuela, A.; Aguirre, V.; Vázquez, R.; Flores-Pérez, F.I. Changes in behavioral and physiological parameters associated with Taenia pisiformis infection in rabbits (Oryctaolagus cuniculus) that may improve early detection of sicks rabbits. World Rabbit Sci. 2011, 18, 21-30.

6. Mawby, D.; Bartges, J.W.; D’Avignon, A.; Laflamme, D.P.; Moyers, T.D.; Cottrell, T. Comparison of Various Methods for Estimating Body Fat in Dogs. J. Am. Anim. Hosp. Assoc. 2004, 40, 109-114. [CrossRef]

7. Baudrand, R.; Carvajal, C.A.; Riquelme, A.; Morales, M.; Solís, N.; Pizarro, M.; Escalona, A.; Boza, C.; Pérez, G.; Domínguez, A.; et al. Overexpression of 11beta-hydroxysteroid dehydrogenase type 1 in hepatic and visceral adipose tissue is associated with metabolic disorders in morbidly obese patients. Obes. Surg. 2010, 20, 77-83. [CrossRef]

8. Yang, Z.; Grinchuk, V.; Smith, A.; Qin, B.; Bohl, J.A.; Sun, R.; Notari, L.; Zhang, Z.; Sesaki, H.; Urban, J.F., Jr.; et al. Parasitic Nematode-Induced Modulation of Body Weight and Associated Metabolic Dysfunction in Mouse Models of Obesity. Infect. Immun. 2013, 81, 1905-1914. [CrossRef]

9. Doenhoff, M.J.; Stanley, R.G.; Griffiths, K.; Jackson, C.L. An anti-atherogenic effect of Schistosoma mansoni infections in mice associated with a parasite-induced lowering of blood total cholesterol. Parasitology 2002, 125, 415-421. [CrossRef]

10. Zepeda, N.; Copitin, N.; Solano, S.; Fernández, A.; Tato, P.; Molinari, J.L. Taenia crassiceps: A secretion-substance of low molecular weight leads to disruption and apoptosis of seminiferous epithelium cells in male mice. Exp. Parasitol. 2011, 128, 184-191. [CrossRef]

11. Korenblat, K.M.; Fabbrini, E.; Mohammed, B.S.; Klein, S. Liver, Muscle, and Adipose Tissue Insulin Action Is Directly Related to Intrahepatic Triglyceride Content in Obese Subjects. Gastroenterology 2008, 134, 1369-1375. [CrossRef] [PubMed]

12. Huerta, N.G.M.; Izquierdo, A.C.; Hernández, J.A.; Pérez, F.I.F.; Pérez-Martínez, M. Histomorphology of Liver, Testicle and Body Fat in Farm Rabbits Fed with an Obesogenic Diet During the Peripuberal Period. Int. J. Morphol. 2015, 33, 1371-1376. [CrossRef]

13. Moore, D.M.; Zimmerman, K.; Smith, S.A. Hematological assessment in pet rabbits: Blood sample collection and blood cell identification. Vet. Clin. North. Am. Exot. Anim. Pract. 2015, 18, 9-19. [CrossRef] [PubMed]

14. Washington, I.M.; Van Hoosier, G.V. Clinical Biochemistry and Hematology. In The Laboratory Rabbit, Guinea Pig, Hamster, and Other Rodents; Elsuckow, M.A., Stevens, K.A., Wilson, R.P., Eds.; Academic Press: Cambridge, MA, USA, 2012; pp. 57-116.

15. Torres, L.; Martins, V.D.; Faria, A.M.C.; Maioli, T.U. The Intriguing Relationship Between Obesity and Infection. J. Infectol. 2018, 1, 6-10. [CrossRef]

16. Mancuso, P.; Gottschalk, A.; Phare, S.M.; Peters-Golden, M.; Lukacs, N.W.; Huffnagle, G.B. Leptin-deficient mice exhibit impaired host defense in Gram-negative pneumonia. J. Immunol. 2002, 168, 4018-4024. [CrossRef] 
17. Wieland, C.W.; Florquin, S.; Chan, E.D.; Leemans, J.C.; Weijer, S.; Verbon, A.; Fantuzzi, G.; Van Der Poll, T. Pulmonary Mycobacterium tuberculosis infection in leptin-deficient ob/ob mice. Int. Immunol. 2005, 17, 1399-1408. [CrossRef]

18. Horbury, S.R.; Mercer, J.G.; Chappell, L.H. Anorexia Induced by the Parasitic Nematode, Nippostrongylus brasiliensis: Effects on NPY and CRF Gene Expression in the Rat Hypothalamus. J. Neuroendocrinol. 1995, 7, 867-873. [CrossRef]

19. Smith, A.G.; Sheridan, P.A.; Harp, J.B.; Beck, M.A. Diet-induced obese mice have increased mortality and altered immune responses when infected with influenza virus. J. Nutr. 2007, 137, 1236-1243. [CrossRef]

20. Flatt, R.; Moses, R. Lesions of experimental cisticercosis in domestic rabbits. Lab. Anim. Sci. 1975, 25, $162-167$.

21. Tanowitz, H.B.; Scherer, P.E.; Mota, M.M.; Figueiredo, L.M. Adipose Tissue: A Safe Haven for Parasites? Trends Parasitol. 2016, 33, 276-284. [CrossRef]

22. De Carvalho, R.V.H.; Soares, S.M.A.; Gualberto, A.C.M.; Evangelista, G.C.M.; Duque, J.A.M.; Ferreira, A.P.; Macedo, G.C.; Gameiro, J. Plasmodium berghei ANKA infection results in exacerbated immune responses from C57BL/6 mice displaying hypothalamic obesity. Cytokine 2015, 76, 545-548. [CrossRef] [PubMed]

23. Wyss, K.; Wångdahl, A.; Vesterlund, M.; Hammar, U.; Dashti, S.; Naucler, P.; Färnert, A. Obesity and Diabetes as Risk Factors for Severe Plasmodium falciparum Malaria: Results From a Swedish Nationwide Study. Clin. Infect. Dis. 2017, 65, 949-958. [CrossRef] [PubMed]

24. Flores-Perez, I.; Pérez-Martínez, M.; Pérez-Torres, A.; Camacho-Arroyo, I.; Garduño-Millán, M.L.; Ramírez-Aquino, R.; Jiménez-Cortez, H.; Hallal-Calleros, C. Histological analysis of the temporal influx of immune cells into hepatic granulomas induced by Taenia pisiformis in rabbits. J. Anim. Plant. Sci. 2018, $28,460-466$.

25. Lukes, S. Changes in the white blood picture during experimental larval ascariasis, toxocariasis and toxascariasis. Folia Parasitol. 1985, 32, 237-245.

26. El-Marzouki, Z.M.; Amin, A.M. Changes in serum lipids of mice experimentally infected with Schistosoma mansoni. J. Egypt. Soc. Parasitol. 1997, 27, 419-429. [PubMed]

27. Romano, M.C.; Ejiménez, P.; Miranda-Brito, C.; Valdez, R.A. Parasites and steroid hormones: Corticosteroid and sex steroid synthesis, their role in the parasite physiology and development. Front. Neurosci. 2015, 9, 224. [CrossRef]

28. Zinsou, J.F.; Janse, J.J.; Honpkehedji, J.Y.; Dejon-Agobé, J.C.; García-Tardón, N.; Hoekstra, P.T.; Massinga-Loembe, M.; Corstjens, P.L.A.M.; Van Dam, G.J.; Giera, M.; et al. Schistosoma haematobium infection is associated with lower serum cholesterol levels and improved lipid profile in overweight/obese individuals. PLOS Negl. Trop. Dis. 2020, 14, e0008464. [CrossRef] [PubMed]

29. Barnard, C.J.; Behnke, J.M.; Gage, A.R.; Brown, H.; Smithurst, P.R. The role of parasite-induced immunodepression, rank and social environment in the modulation of behaviour and hormone concentration in male laboratory mice (Mus musculus). Proc. R. Soc. B Biol. Sci. 1998, 265, 693-701. [CrossRef]

30. Muehlenbein, M.P.; Watts, D.P. The costs of dominance: Testosterone, cortisol and intestinal parasites in wild male chimpanzees. Biopsychosoc. Med. 2010, 4, 21. [CrossRef]

31. Metwaly, M.S.; Dkhil, M.A.; Gewik, M.M.; Al-Ghamdy, A.O.; Al-Quraishy, S. Induced metabolic disturbance and growth depression in rabbits infected with Eimeria coecicola. Parasitol. Res. 2013, 112, 3109-3114. [CrossRef]

32. Hallal-Calleros, C.; Morales-Montor, J.; Vázquez-Montiel, J.A.; Hoffman, K.; Nieto-Rodriguez, A.; Flores-Pérez, F.I. Hormonal and behavioral changes induced by acute and chronic experimental infestation with Psoroptes cuniculi in the domestic rabbit Oryctolagus cunicu. Parasites Vectors 2013, 6, 361. [CrossRef] [PubMed]

33. Tomlinson, J.W.; Sherlock, M.; Hughes, B.; Hughes, S.V.; Kilvington, F.; Bartlett, W.; Courtney, R.; Rejto, P.; Carley, W.; Stewart, P.M. Inhibition of 11beta-hydroxysteroid dehydrogenase type 1 activity in vivo limits glucocorticoid exposure to human adipose tissue and decreases lipolysis. J. Clin. Endocrinol. Metab. 2007, 92, 857-864. [CrossRef] [PubMed]

34. Birkner, E.; Kasperczyk, S.; Kasperczyk, A.; Zalejska-Fiolka, J.; Zwirska-Korczala, K.; Stawiarska-Pieta, B.; Grucka-Mamczar, E. Metabolic and antioxidative changes in liver steatosis induced by high-fat, low-carbohydrate diet in rabbits. J. Physiol. Pharmacol. 2005, 56, 45-58. [PubMed] 
35. Larralde, C.; Morales, J.; Terrazas, L.I.; Govezensky, T.; Romano, M. Sex hormone changes induced by the parasite lead to feminization of the male host in murine Taenia crassiceps cysticercosis. J. Steroid Biochem. Mol. Biol. 1995, 52, 575-580. [CrossRef]

36. González-Mariscal, G.; Melo, A.I.; Zavala, A.; Beyer, C. Chin-marking behavior in male and female New Zealand rabbits: Onset, development, and activation by steroids. Physiol. Behav. 1992, 52, 889-893. [CrossRef]

37. Mykytowycz, R. Territorial Function of the Chin Gland Secretion in the Rabbit, Oryctolagus cuniculus (L.). Nat. Cell Biol. 1962, 193, 799. [CrossRef]

38. Mykytowycz, R. Further observations on the territorial function and histology of the submandibular cutaneous (chin) glands in the rabbit, Oryctolagus cuniculus (L.). Anim. Behav. 1965, 13, 400-412. [CrossRef]

39. González-Mariscal, G.; Melo, A.; Zavala, A.; Chirino, R.; Beyer, C. Sex steroid regulation of chin-marking behavior in male New Zealand rabbits. Physiol. Behav. 1993, 54, 1035-1040. [CrossRef]

40. Arias-Hernández, D.; Flores-Pérez, F.I.; Domínguez-Roldan, R.; Báez-Saldaña, A.; Carreon, R.A.; García-Jimenez, S.; Hallal-Calleros, C. Influence of the interaction between cysticercosis and obesity on rabbit behavior and productive parameters. Vet. Parasitol. 2019, 276, 108964. [CrossRef]

41. Power, M.L.; Schulkin, J. Sex differences in fat storage, fat metabolism, and the health risks from obesity: Possible evolutionary origins. Br. J. Nutr. 2008, 99, 931-940. [CrossRef]

42. Zhao, S.; Chu, Y.; Zhang, C.; Lin, Y.; Xu, K.; Yang, P.; Fan, J.; Liu, E. Diet-induced central obesity and insulin resistance in rabbits. J. Anim. Physiol. Anim. Nutr. 2007, 92, 105. [CrossRef] [PubMed]

43. Dhurandhar, N.V. Contribution of pathogens in human obesity. Drug News Perspect. 2004, 17, $307-313$. [CrossRef] [PubMed]

44. Greenway, F. Virus-induced obesity. Am. J. Physiol. Regul. Integr. Comp. Physiol. 2006, 290, R188-R189. [CrossRef] [PubMed]

45. Alzaga, V.; Vicente, J.; Villanua, D.; Acevedo, P.; Casas, F.; Gortázar, C. Body condition and parasite intensity correlates with escape capacity in Iberian hares (Lepus granatensis). Behav. Ecol. Sociobiol. 2007, 62, 769-775. [CrossRef]

46. NRC 1997. Nutritional Requeriments Codex. World Wide Web Electronic Publication. Available online: http://www.foedevarestyrelsen.dk/SiteCollectionDocuments/25_PDF_word_filer\%20til\%20download/ 07kontor/Maerkning/Codex\%20guidelines\%20nutrition\%20and\%20health\%20claims.pdf (accessed on 1 September 2020).

47. Antic, V.; Tempini, A.; Montani, J.-P. Serial changes in cardiovascular and renal function of rabbits ingesting a high-fat, high-calorie diet. Am. J. Hypertens. 1999, 12, 826-829. [CrossRef]

48. Beaver, B.V.; Reed, W.; Leary, S.; McKiernan, B.; Bain, F.; Schultz, R.; Bennett, B.T.; Pascoe, P.; Shull, E.; Cork, L.C.; et al. Report of the AVMA panel on euthanasia. J. Am. Vet. Med. Assoc. 1993, 218, 669-696.

Publisher's Note: MDPI stays neutral with regard to jurisdictional claims in published maps and institutional affiliations.

(C) 2020 by the authors. Licensee MDPI, Basel, Switzerland. This article is an open access article distributed under the terms and conditions of the Creative Commons Attribution (CC BY) license (http://creativecommons.org/licenses/by/4.0/). 